\title{
Use of Web 2.0 by students in the Faculty of Information Science and Communications at Mzuzu University, Malawi
}

\begin{tabular}{|c|c|}
\hline \multicolumn{2}{|c|}{$\begin{array}{l}\text { Authors: } \\
\text { Winner D. Chawinga }{ }^{1} \\
\text { Sandy Zinn }{ }^{2}\end{array}$} \\
\hline \multicolumn{2}{|c|}{$\begin{array}{l}\text { Affiliations: } \\
{ }^{1} \text { Department of Library and } \\
\text { Information Science, Mzuzu } \\
\text { University, Malawi }\end{array}$} \\
\hline \multicolumn{2}{|c|}{$\begin{array}{l}{ }^{2} \text { Department of Library and } \\
\text { Information Science, } \\
\text { University of the Western } \\
\text { Cape, South Africa }\end{array}$} \\
\hline \multicolumn{2}{|c|}{$\begin{array}{l}\text { Corresponding author: } \\
\text { Winner Chawinga, } \\
\text { winnchawinga@gmail.com }\end{array}$} \\
\hline \multicolumn{2}{|c|}{$\begin{array}{l}\text { Dates: } \\
\text { Received: } 26 \text { May } 2015 \\
\text { Accepted: } 19 \text { Nov. } 2015 \\
\text { Published: } 27 \text { May } 2016\end{array}$} \\
\hline \multicolumn{2}{|c|}{$\begin{array}{l}\text { How to cite this article: } \\
\text { Chawinga, W.D. \& Zinn, S., } \\
2016 \text {, 'Use of Web } 2.0 \text { by } \\
\text { students in the Faculty of } \\
\text { Information Science and } \\
\text { Communications at Mzuzu } \\
\text { University, Malawi', South } \\
\text { African Journal of } \\
\text { Information Management } \\
\text { 18(1), a694. http://dx.doi. } \\
\text { org/10.4102/sajim.v18i1.694 }\end{array}$} \\
\hline \multicolumn{2}{|c|}{$\begin{array}{l}\text { Copyright: } \\
\text { ( ) 2016. The Authors. } \\
\text { Licensee: AOSIS. This work } \\
\text { is licensed under the } \\
\text { Creative Commons } \\
\text { Attribution License. }\end{array}$} \\
\hline \multicolumn{2}{|l|}{ Read online: } \\
\hline 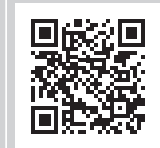 & $\begin{array}{l}\text { Scan this QR } \\
\text { code with your } \\
\text { smart phone or } \\
\text { mobile device } \\
\text { to read online. }\end{array}$ \\
\hline
\end{tabular}

Background: Over the years, advancements in Internet technologies have led to the emergence of new technologies such as Web 2.0, which have taken various sectors including higher education by storm. Web 2.0 technologies are slowly but surely penetrating higher education in developing countries with much hype, according to the literature. This justifies the need for original research that aims at demystifying the application and exploiting the promises that come along with these so-called versatile technologies.

Objectives: The specific objectives of the study were to ascertain students' awareness of and familiarity with Web 2.0 technologies, to determine the purposes for which students use Web 2.0 technologies, and to identify the factors that affect students' use or non-use of Web 2.0 technologies.

Method: A mixed-methods approach was adopted. Firstly, a questionnaire was sent to 186 students; secondly, the curricula of the two departments in the Faculty of Information Science and Communication (ISC) were analysed; finally, follow-up interviews were conducted with seven lecturers in the Faculty of ISC.

Results: The study found that students use Web 2.0 technologies to search for information, to communicate with lecturers, to submit assignments and to communicate with friends on academic work. Wikipedia, WhatsApp, Google Apps and YouTube are the Web 2.0 technologies most used by students. Poor bandwidth (Internet connection) coupled with the absence of Wi-Fi (wireless Internet connection) prevents the successful adoption of Web 2.0 by students.

Conclusion: Web 2.0 can have a profound impact on undergraduate students and lecturers in teaching and learning. The research results indicated a high awareness of a wide range of Web 2.0 technologies, with social networks being the commonly used one. There is a need for more training to increase awareness of and familiarity with new Web 2.0 technologies. The problem of poor bandwidth needs to be addressed by the university management in order to gain significant benefits.

\section{Introduction}

In the 21st century, countries across the globe are increasingly relying on Information and Communication Technologies (ICTs) to address a wide range of issues. The term 'ICT' is used almost interchangeably with the Internet (Beebe 2004). The Internet is an interconnected network of networks, and it helps to connect millions of computers and millions of users around the world (Tatnall et al. 2003). The Internet together with its applications has proved to be a remarkably convenient, cheap and affordable avenue for bringing people together to share data, information and knowledge, thereby enlarging the range of human capabilities. Because a new wave of Internet technologies, such as podcasting and websites designed for collaborative content (e.g. Wikipedia), social networking (e.g. Facebook, Twitter and WhatsApp), multimedia sharing (e.g. Flickr and YouTube), social tagging (e.g. Delicious) (Alexander 2006:33; Grosseck 2009:479; Huang, Hood \& Yoo 2013:57), and virtual gaming and social worlds (e.g. World of Warcraft and Second Life, respectively) (Kaplan \& Haenlein 2010:60), have been adopted by quite a number of sectors, the higher education sector has also embraced the appeal of these Internet technologies. In South Africa, for example, Zinn (2009) found that the e-learning system permits students to communicate with a course facilitator and fellow students via email, instant messaging, chats and the discussion forum that the system offers. Such communication can be seen as one of the ways the Internet has fundamentally revolutionised higher education. Recently, the use of the Internet in educational activities has been boosted by the emergence of Web 2.0 technologies. In this study, the focus is on the use of Web 2.0 by university students. 


\section{Conceptualising Web 2.0}

The term 'Web 2.0' was popularised by O'Reilly (2005) and defined as follows:

Web 2.0 applications are those that make the most of the intrinsic advantages of that platform: delivering software as a continuallyupdated service that gets better the more people use it, consuming and remixing data from multiple sources, including individual users, while providing their own data and services in a form that allows remixing by others, creating network effects through an 'architecture of participation' and going beyond the page metaphor of Web 1.0 to deliver rich user experiences.

Zimmer (2008) sees Web 2.0 as frameworks that represent a deflation of the boundaries that exist between producers of content and users, thereby leading to more participation (interaction) and consumption. Ultimately, such a blurring of the boundaries permits every Internet user an opportunity to use new Internet technologies to conveniently organise and distribute content, to instantly interact with a wider community and to express themselves (being visible to the wider community). To this end, Zimmer argues, the power of these new technologies lies in their capability to bring about collaboration and networks in cyberspace. Alexander (2006) emphasises that Web 2.0 allows users to play a more foundational role in the creation, management and distribution of content. Without doubt, users also own content that they create or co-create, access and share. Although the definitions of Web 2.0 are open to debate, (see Grosseck 2009:479), they all draw their wisdom from the initial definition propounded by O'Reilly (2005). Thus, despite the different wording used to define Web 2.0, most users see it as the social use of the Web that affords users an opportunity to participate in content creation (information and knowledge) and management, content that they can share online with little or no restrictions because of the openness and devolution of the Web. Based on these definitions and characterisation of Web 2.0, it might be safe to suggest that Web 2.0 is concerned more with the free flow of information from site to site, from user to user, and arguably, this is one of the most groundbreaking features of Web 2.0.

An analysis of the preceding characterisation persuades us to believe that the development of Web 2.0 was motivated by the limitations of Web 1.0 in bringing together Internet users, that is, both consumers of Internet-based information or content and content creators. The major weakness of Web 1.0 according to Kwanya, Stilwell and Underwood (2012) was that users of the Internet were seen as 'captives' or mere consumers of information or data that were posted or uploaded on the Internet by experts or companies. It can therefore be said that by sorting out the apparent limitations of Web 1.0 through the introduction of Web platforms that narrowed the gap in online interactions is how Web 2.0 emerged. Since O'Reilly (2005) heralded the first definition of Web 2.0, there have been various definitions of Web 2.0. It is apparent from the literature that Web 2.0 is still being interpreted and understood differently, with some scholars focussing on the aspect of technology whilst others focus on the aspect of the user. For example, whereas Komiko (2007) understands Web 2.0 as an associated technology to include blogs, social networking sites, shared bookmarks and image sites, that it is intrinsically linked to the developing 'semantic Web', Abram (2007) sees Web 2.0 as the more human aspects of interactivity, conversations, interpersonal networking, personalisation and individualism. In this study, Abram's (2007) understanding of Web 2.0 has been adopted, that is, the focus on a more human aspect of instant interactivity through the use of Web 2.0 platforms such as Twitter, YouTube, Viber, Facebook and others that make instant communication a reality. However, despite researchers defining Web 2.0 in various ways, the bottom line is that all definitions revolve around the initial definition provided by O'Reilly (2005). In the current study, Web 2.0 is seen as the Internet-based applications that make the use of the Internet more sociable, more user friendly, more manipulative, more flexible, more cost-effective and, above all, more interactive by minimising physical barriers and distance as restrictions to communication. Kwanya, Stilwell and Underwood (2012) caution that, although the term Web 2.0 suggests a new version of the Web, it does not refer to an update of the Internet or the World Wide Web technical standards but to changes in the way they are used.

\section{Status of ICTs in Malawi}

In Malawi, communication networks and ICT infrastructure are currently thriving, and this development has increased accessibility to Internet facilities for many Malawians (Chaputula 2012). Through the Malawi Communications Regulatory Authority in partnership with the International Telecommunication Union, the government has developed a number of strategies to promote public access to ICTs in Malawi. Chisa (2006:25) reports that the Malawi government through the Malawi Telecommunications Limited has installed a fibre-optic cable network worth US\$50 million, which has relatively improved the country's bandwidth. Connecting most parts of Malawi, the fibre builds the networks that form the country's national fibre-optic backbone, providing voice, data, fax and radio communication systems. Mobile service providers have also helped to propel the permeation of ICT facilities. The growth of mobile technology, coupled with the ongoing liberalisation of Malawi's telecom market, is spurring the proliferation of ICT services, especially the Internet, across the country. Chaputula and Boadi (2010) and Mtingwi and Van Belle (2012) independently report that the emergence of mobile phone services has enabled many Malawians who own Internetenabled phones to access the Internet anytime. Most mobile service providers provide their customers with smartphones and affordable data bundle prices.

\section{Background of the study}

Mzuzu University (MZUNI) is situated in Mzuzu City, some $350 \mathrm{~km}$ north of the capital, Lilongwe. It was established in 1997 as a second national public university in Malawi, with the mission to provide high-quality education, training, research and complementary services to meet the 
technological, social and economic needs of individuals and communities in Malawi (Mzuzu University 2015:2). As of 2014, MZUNI had a total population of 3200 registered students across its five faculties - Education, Information Science and Communication (ISC), Environmental Health, Environmental Sciences and Hospitality Management and Tourism (Mzuzu University 2015). Established in 2004, the Faculty of ISC has been tasked to address the acute shortage of personnel in the information sector and to meet the information and technology needs of Malawi and beyond. It has two departments, Library and Information Science and ICT, which offer degree programmes in Library and Information Science (LIS) and ICT, respectively. Over the years, MZUNI has taken some initiatives in investing in ICT, particularly Internet technologies (Nyirongo 2009). This study attempts to show the use of Web 2.0 technologies by students at MZUNI - their awareness of and familiarity with these technologies.

\section{Problem statement and research questions}

The problem of the study originates from observations made by one of the researchers of this study, who is an employee of MZUNI. The researcher observed that the Faculty of ISC has two computer laboratories (one with 30 desktop computers and the other with 60 laptops), where a population of 247 students access the Internet for free. Similarly, the university library has a computer laboratory (commonly called the Internet room), where students access Internet services at a subsidised fee. Two previous studies (Chaputula 2012; Nyirongo 2009) have independently shown that MZUNI has been investing in computer and Internet technologies. Given the availability of computer and Internet technologies, the assumption could be that students use Web 2.0 technologies for academic purposes, as is the case in other institutions of higher learning (see Hartshorne \& Ajjan 2009; Huang, Hood \& Yoo 2013; Mugwanya, Marsden \& Boateng 2011; Sadaf, Newby \& Ertmer 2012). This study therefore sought to investigate the use of Web 2.0 by students in the Faculty of ISC. The study answered the following specific research questions:

- What is the current awareness of and familiarity with Web 2.0 technologies amongst students in the Faculty of ISC?

- For what educational purpose do students in the Faculty of ISC use Web 2.0 technologies, and which Web 2.0 technologies do they use the most?

- What are the factors that influence students in the Faculty of ISC to adopt Web 2.0 technologies?

\section{Literature review: Web 2.0 in higher education}

The literature in relation to the use of Web 2.0 technologies by university students is reviewed in this section. The section has two parts. The first part discusses examples of Web 2.0 and their characteristics. By reviewing prior studies, the second part discusses the university students' use of Web 2.0.

\section{Some forms of Web $\mathbf{2 . 0}$}

Web 2.0 is known by various names, which emerged as a result of its characteristics, and some of them are 'participatory media' (Bull et al. 2008:106), 'social digital technologies' (Palfrey \& Gasser 2008:1) and 'second wave of the World Wide Web' (Azab, Abdelsalam \& Gamal 2013). Examples of some popular forms of Web 2.0 technologies that are widely used in higher education are blogs, wikis, Really Simple Syndication (RSS) feeds, YouTube, Flickr, Facebook, Twitter, Skype, podcasts, Google Apps and WhatsApp (Al-Qirim 2010; Armstrong \& Franklin 2008; Harinarayana \& Raju 2010:74; Hough \& Neuland 2012; Huang, Hood \& Yoo 2013:57; Luo 2010:38; Makori 2011:35; Sandars \& Schroter 2007).

\section{Characteristics of Web $\mathbf{2 . 0}$}

There are a number of characteristics that uniquely identify Web 2.0 technologies. According to O'Reilly (2005), Habib (2006), Musser and O'Reilly (2007) and Al-Qirim (2010), these are some core features:

- Web 2.0 allows users to customise the Web by adding content to, altering and editing the pages that they browse or visit. Such flexibilities of Web 2.0 qualify it to be called a read/write Web, a characteristic that Web 1.0 or a readonly Web lacks. Blogs, Twitter, Facebook and wikis are some of the examples of read/write technologies that promote conversations amongst users instead of just broadcasting, as is the case with Web 1.0, which mimics the broadcasting of a speech on television or radio.

- Web 2.0 provides platforms on which users can execute applications straight from their Web browsers. For example, users can use applications such as Google Drive, Dropbox and MySpace to execute, manage and own their content or data.

- Web 2.0 technologies have a 'long tail' (O'Reilly 2005), a phrase used to characterise users' freedom to publish and distribute content and other resources at a minimal cost on the Web. That is, Web 2.0 has eliminated barriers to storage space as people can now store their photos, videos and data on Web-based applications for free or at a minimum cost. The characteristic extends to its ability to provide services to small or community groups with common interests - communities of practice.

- Web 2.0 technologies accord users an opportunity to add value to the content that they access, and this leads to a seamless exchange and building of a robust body of knowledge that is sometimes called collective intelligence (Kwanya, Stilwell \& Underwood 2012). This suggests that in the Web 2.0 era, knowledge is no longer monopolised by its creators. Rather, it is decentralised, that is, accessed and co-created by users who may be geographically scattered. Wikipedia provides an excellent example where many users access, share and contribute knowledge, which in turn attracts many new users.

- Web 2.0 does not require users to have programming skills or specialist knowledge as the associated tools and technologies are simple to use and provide user-friendly ways to loosely share and process data sets between partners. 
- Web 2.0 continues to develop and is not dependent on predetermined models. Web 2.0 structures and behaviours are flexible, and they emerge over time. Because they are flexible and adaptive, Web 2.0 technologies allow the formulation of solutions that respond to real and current world issues and needs. Proponents of Web 2.0 argue that the real success of these technologies comes from collaboration and not monopoly. They maintain that in an educational setting, Web 2.0 technologies result in quick feedback for lecturers from students and vice versa, reflective and collaborative learning, transformation of the world into a classroom available $24 / 7$, and wider choices of channels/mediums for information creation and sharing (Dzvapatsva, Mitrovic \& Dietrich 2014; Grosseck 2009:479; Menkhoff et al. 2014; Wheeler 2010:106).

To simplify the understanding of Web 2.0, O'Reilly (2005) proposed a meme map (see Figure 1), which attempts to demonstrate the concept of Web 2.0 and various aspects related to the concept. The centred orange rectangle denotes the essential principles of Web 2.0, such as Web 2.0 as a platform, as a read/write Web and as collective intelligence.
The green oval shapes above, connected to the centred orange rectangle, embody the tools of Web 2.0. The beige oval shapes, which connect to the centred orange rectangle from the middle and downwards, show the characteristics and the use of these technologies.

\section{Use of Web 2.0 by students in higher education}

The literature is reviewed along the following lines, which fall within the main objectives of the study:

- Awareness of and familiarity with Web 2.0 technologies.

- Purposes of Web 2.0 technologies in teaching and learning and Web 2.0 technologies used the most.

- Factors for use or non-use of Web 2.0

\section{Awareness of and familiarity with Web 2.0 technologies}

Sandars and Schroter (2007) investigated the familiarity with and use of Web 2.0 technologies amongst medical undergraduate students in the United Kingdom (UK).

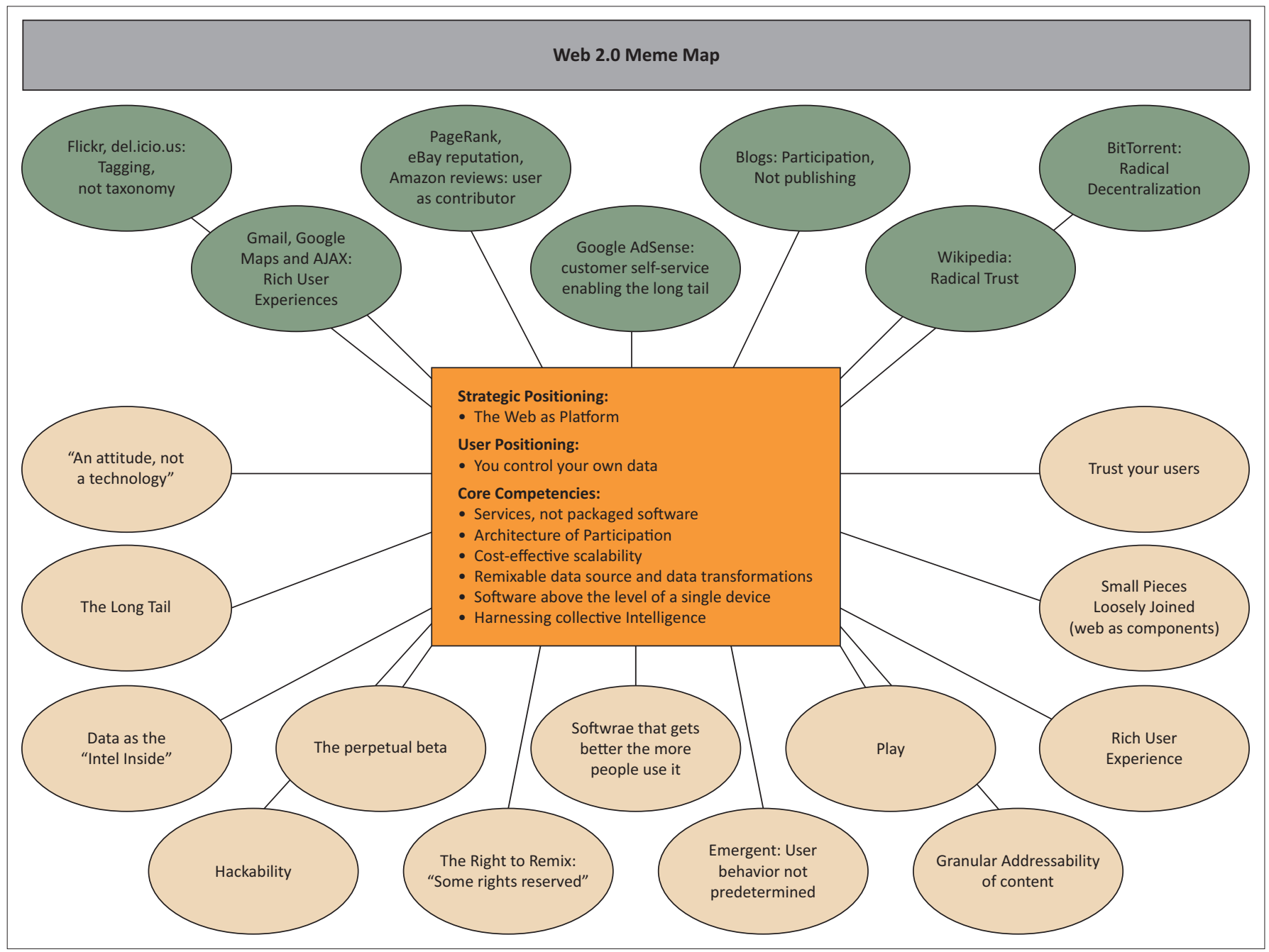

Source: O'Reilly, T., 2005, What is Web 2.0: Design patterns and business models for the next generation of software?, O'Reilly Media, Sebastopol, viewed 10 July 2014 , from https:// mpra.ub.uni-muenchen.de/4578/1/MPRA_paper_4578.pdf

FIGURE 1: The Web 2.0 meme map. 
The study revealed that although the overall adoption of Web 2.0 was relatively high, the application of some technologies such as podcasts was still marginal and there was a need to research more on some basic concepts such as awareness and familiarity for it to hold its ground. In this context, according to Ajjan and Hartshorne (2008), Mugwanya, Marsden and Boateng (2011), Sadaf, Newby and Ertmer (2012) and Huang, Hood and Yoo (2013), awareness means students' knowledge about the existence of Web 2.0 technologies, whereas familiarity refers to the skills and abilities for operating or using the Web 2.0 technologies. Some students in South Africa have misconceptions about some Web 2.0 technologies, podcasts in particular, because of a lack of knowledge, familiarity and awareness, according to the findings reported by Mugwanya, Marsden and Boateng (2011). Mugwanya et al. investigated the academic staffs' and students' experience in podcasting at the University of Cape Town in South Africa, focusing on identifying their current experiences, familiarity and knowledge. The study revealed that only $28 \%$ of the students were aware of and familiar with podcasts, and the results showed further that 'some students viewed them [podcasts] as extra lessons which they did not need' (p. 278).

Provision of awareness programmes about Web 2.0 technologies for students and lecturers is reported to be bearing fruit in some universities (Azab, Abdelsalam \& Gamal 2013). Azab, Abdelsalam and Gamal (2013) investigated the use of Web 2.0 amongst academic staff and students in Egyptian public universities. The results showed that blogs, wikis and social networks are popular amongst students and academic staff (mainly used for research activities and sharing academic content), attributing the success story to frequent awareness and training programmes offered by the university. The researchers report further that the students and lecturers are of the view that such awareness programmes should be conducted regularly. This is necessary especially taking into account that some researchers (Franklin \& Harmelen 2007; Tyagi 2012) have independently observed that the sheer number of Web 2.0 technologies that have overlapping functionalities means that it can be difficult for students and lecturers to choose amongst them.

Although most of the studies and scholarly articles reviewed in this section suggest that awareness and familiarity are key determinants for the uptake by academic staff and students of Web 2.0 technologies, they are not very clear about who should be responsible for providing such awareness programmes. The present study explores, amongst other issues, how best these skills and abilities can be imparted to students and lecturers.

\section{Purpose and most popular choices of Web 2.0}

Web 2.0 technologies are extensively used for communication amongst students and lecturers in some universities. Using a survey-based methodology, Li and Pitts (2009) found that, at a public US university in the southeast, Web 2.0 technologies facilitate flexible and innovative ways of communication between lecturers and students. Prior studies (Augustsson 2010; Churchill 2009; Dzvapatsva, Mitrovic \& Dietrich 2014; Eyyama, Menevi \& Dogruer 2011; Soares 2008) show that students can use Web 2.0 technologies to publish their own writings, to discuss group assignments and to conduct peer reviews for one another's work.

Augustsson (2010) investigated collaborative activities that were implemented using VoiceThread (a form of Web 2.0) by undergraduate psychology students. The researcher found that VoiceThread is used to support students' reflections concerning their own and their friends' thoughts and emotions.

After subjecting university students studying English as a foreign language to the use of blogs at a Brazilian university for a semester, Soares (2008) decided to investigate the students' perception about blogs as learning tools. The study shows that students used blogs to communicate with other students and to improve their writing skills in the Englishlanguage course by accessing tutorials in the form of podcasts and videos shared on their blogs and YouTube. The findings corroborate those of Churchill (2009), who experimented with the use of wikis, blogs, social networking and social bookmarking as teaching and learning tools at the University of Hong Kong, where it was noted that Web 2.0 technologies are used by students to read the blogs of others, receive comments, preview tasks of others and read feedback received from lecturers. Students subscribe to RSS feeds to access information and the latest posts from students' and lecturers' blogs, wikis and websites. The findings are reinforced by observations made by Eyyama, Menevi and Dogruer (2011), who postulate that Web 2.0 technologies have tremendously improved communication between students and lecturers. Similar findings have been recently reported in South Africa by Dzvapatsva, Mitrovic and Dietrich (2014), who conclude that social networks have improved students' communication with fellow students and lecturers. Some Web 2.0 technologies such as Twitter, YouTube and Facebook are popular and extensively used by students and lecturers for personal purposes; Kumar (2009) cautions that the popularity of some Web 2.0 technologies amongst students and lecturers does not necessarily mean that they are being utilised for teaching and learning.

\section{Factors for use or non-use of Web 2.0}

Since the emergence of Web 2.0 technologies, quite a number of studies (Ajjan \& Hartshorne 2008; Campion \& Nailda 2012; Gaffar, Singh \& Thomas 2011) have been conducted to determine the factors that influence the acceptance or rejection of these technologies by university students. In a study that aimed at assessing the factors that enabled students and lecturers at a US university to use Web 2.0 technologies, Ajjan and Hartshorne noted that ease of use, usefulness and compatibility of these technologies with students' academic activities contributed significantly to their adoption. Students also used these technologies because 
they were encouraged by their lecturers. Similar findings have been reported in Spain, where Campion and Nailda (2012) noted that students use Web 2.0 because these technologies are perceived as adding value to their teaching and learning activities. However, students lack the skills and technical know-how to use some of these technologies and are thus discouraged from integrating them in their studies.

Other factors that affect the use or non-use of these Internet technologies, according to Chiu and Wang (2008), Ibrahim, Khalil and Jaafar (2011), Sadaf, Newby and Ertmer (2012) and Huang, Hood and Yoo (2013), are performance expectancy, effort expectancy, social influence and facilitating conditions, perceived learning and enjoyment, and collaboration and engagement. By adopting the unified theory of acceptance and use of technology (Ibrahim, Khalil \& Jaafar 2011; Venkatesh et al. 2003), Huang, Hood and Yoo (2013) investigated 432 college students' perceptions regarding the use of Web 2.0 for learning. The researchers found that regardless of gender, the students found wikis, blogs, and online video sharing (e.g. YouTube) useful in their studies because these Internet technologies enabled them to complete their academic assignments quickly and increased their productivity. However, the students did not perceive online games and social networking tools as viable applications that could effectively assist them in learning tasks. 'Although participants considered social networking tools enjoyable to use [but not enjoyable learning], they did not see them as means to enhance productivity in learning' (p. 63).

Another important motivating factor for the uptake of these Internet technologies according to Menkhoff et al. (2014) is their contribution to student-centred learning. Menkhoff et al. argue that Web 2.0 enables students to have 'a voice, to be more engaged and to interact more freely with both their peers and the instructor via knowledge sharing and Twitter discussions'. This means that students, who are expectantly captive in a traditional approach to teaching, are increasingly offered an opportunity to provide prompt feedback to instructors, an element that Schroeder and Greenbowe (2009) and Jones (2015:93) say leads to the much treasured student-centred learning approach. A learnercentred approach in this case refers to a teaching style in which the teacher acts as a facilitator to student learning (Mascolo 2009), students have a high level of choice and they actively participate in constructing content $\left(\mathrm{O}^{\prime} \mathrm{Neill} \&\right.$ McMahon 2005). Apart from acting as platforms for collaboration, interaction, co-creation and the sharing of educational content amongst students (see Hartshorne \& Ajjan 2009), these Internet technologies have made inroads into universities 'because of the need for students to develop 21st century skills as well as the potential value of these technologies for teaching and learning' (Sadaf, Newby \& Ertmer 2012:171).

The availability of Wi-Fi (wireless Internet connection) is another factor that contributes to the adoption of Internet technologies in teaching and learning (Nyirongo 2009; Stav et al. 2010). The researchers independently argue that apart from being relatively cheap, Wi-Fi does not restrict the students to being in the vicinity of the instructor or confined to one Internet access point.

Issues to do with limited access to the Internet and shortage of computers negatively affect the adoption of these technologies by students at the Caribbean University (Gaffar, Singh \& Thomas 2011). In Africa, Gakio (2006) reports about poor bandwidth, where, on an average, the uplink and downlink are 706 and $1254 \mathrm{Kbps}$ respectively. Poor bandwidth and frequent electricity outages affect the adoption of Internet technologies by institutions of higher learning in Africa (Lwoga 2012:96). However, there seems to be some progress with regard to the penetration of the Internet into the African region, according to one of the most recent reports by the International Telecommunication Union (2014), which indicates that:

the number of Internet users has grown steadily, from 6\% in 2008 to $16 \%$ in 2013 and that close to $7 \%$ of households in Africa now have Internet access at home, compared to only $2 \%$ in 2008.

\section{Theoretical framework: Decomposed theory of planned behaviour}

The literature is replete with theories and models that attempt to explain why people accept or reject technologies. In this study, the decomposed theory of planned behaviour (DTPB) by Taylor and Todd (1995) was adopted. Many researchers, including Ajjan and Hartshorne (2008), Hartshorne and Ajjan (2009), Mugwanya, Marsden and Boateng (2011), and Campion and Nailda (2012), have used this theory extensively and successfully to understand the acceptance or rejection of Web.2.0 in university environments. Sadaf, Newby and Ertmer (2012) used DTPB to determine the factors influencing pre-service teachers' intention to use Web 2.0 technologies in their classrooms. Ajjan and Hartshorne (2008) used the same model to assess the factors that enabled students and lecturers to use Web 2.0 technologies at a US university, whereas Campion and Nailda (2012) used DTPB to investigate the factors that influenced the use of Web 2.0 by students and lecturers at some Spanish universities. In DTPB, Taylor and Todd (1995) identify three factors affecting the adoption of an innovation: attitude, subjective norms and perceived behaviour control.

Attitude is about the perceptions that individuals hold towards a particular innovation, and it is determined by three factors: perceived usefulness, ease of use and compatibility. Davis (1989:320) defines perceived usefulness as the extent to which individuals believe a technology can improve their job performance. If students perceive the technology to have a characteristic of adding value, they are likely to adopt it in their academic activities. According to Rogers (2003:70), ease of use is seen as the degree to which a technology is easy to understand and operate. Should students find Web 2.0 technologies easy to use, the assumption is that they are likely to adopt 
these technologies. Compatibility is perceived as the extent to which the technology complements the already existing activities, experiences and values of individuals. In this case, students are likely to adopt these technologies if they perceive them as compatible with their learning experiences and practices.

Subjective norms are about the social influences that motivate an individual to start using a particular technology (Ajzen 1991:202). Borrowing from prior studies (Hartshorne \& Ajjan 2009; Sadaf, Newby \& Ertmer 2012), this study divides subjective norms into two groups: superiors (lecturers) and peers (colleagues/fellow students). The assumption is that if lecturers feel that the adoption of Web 2.0 technologies improves students' learning, they may incorporate them in their academic activities and may require their students to adopt them (Web 2.0) as well (Ajjan \& Hartshorne 2008). Similarly, students who see the value of Web 2.0 technologies after trying them may influence fellow students to adopt them (Shihab 2008).

In terms of perceived behaviour control, Taylor and Todd (1995:156) identify two important factors that influence the adoption of technologies: self-efficacy and facilitating conditions. The assumption is that, even if a particular technology is easy to use, has practical value and is compatible with an individual's tasks, there should be willingness or readiness (self-efficacy) on the part of the individual to use these technologies (Taylor \& Todd 1995). This study describes students' self-efficacy as their willingness or readiness to use Web 2.0 technologies to supplement their in-class learning activities. Greater self-efficacy to use technological applications is likely to lead to a higher level of behavioural intentions and actual usage (Taylor \& Todd 1995).

Facilitating conditions are environmental in nature (Sadaf, Newby \& Ertmer 2012:177), and according to Ajjan and Hartshorne (2008:73) and Sadaf, Newby and Ertmer (2012), these factors include time, money, software, hardware and other resources that may be needed to use the technology. In this study, additional facilitating resources may include computers, high Internet bandwidth, and availability and accessibility of Wi-Fi. The assumption of this study is that if the resources mentioned are available, students are likely to be motivated to use Web 2.0 technologies in their academic undertakings. Figure 2 provides a summary of the DTPB.

\section{Research design and methods}

This study is part of a larger study that investigated the use of Web 2.0 by students and lecturers in the Faculty of ISC at Mzuzu University in Malawi. However, in this article, only the findings related to students are reported on.

A case study design was adopted that is understood to have the capacity for triangulating the findings. According to Hartley (2004:325), the chosen design helps understand the impact and influence that the organisational and environmental contexts are having on social processes. By adopting a case study design, the study enabled an in-depth

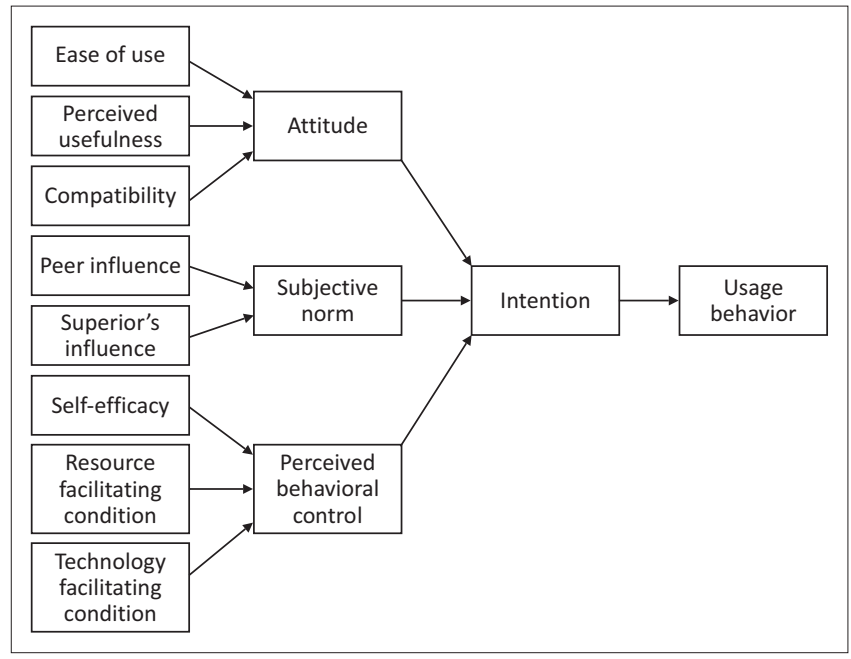

Source: Taylor, S. \& Todd, P.A., 1995, 'Understanding information technology usage: A test of competing models', Information Systems Research 6(2), 144-176. http://dx.doi.org/10.1287/ isre.6.2.144

FIGURE 2: The decomposed theory of planned behaviour.

understanding and a holistic view of the student's use of Web 2.0. Researchers such as McMillan (2004) state that one of the key advantages of a case study design is that it allows researchers to collect both qualitative and quantitative data either in phases or simultaneously in a single study.

\section{Participants}

The study was conducted at the Faculty of ISC because it is an important training centre for ICTs and related courses in Malawi. The participants of the study were undergraduate students pursuing their 4-year programmes in ICT and LIS. These students join the university with very little or no ICT skills because most of the secondary schools in Malawi, from which the university selects these students, do not offer ICT or related courses. The faculty requires these students to register for two compulsory ICT courses (Enduser Computing as well as Computer and Communication Technology) in the first year with the aim of equipping them with the basic ICT skills and knowledge. In the later years of their studies, students in both departments pursue other ICT-related compulsory courses, which include Database Management Systems, Web Design, Instructional Media and Technology and Computer Networks. Apart from doing the courses mentioned, students in LIS concentrate on LIS courses, whereas ICT students concentrate on studying many other ICT-related courses until they graduate.

The student respondents were identified purposively based on three criteria. Participants had to have been exposed to various Internet technologies and be aware of various Internet access points on the MZUNI campus or outside it. In addition, students needed to have completed at least two ICT compulsory courses. Following these criteria, it turned out that only students in the second, third and fourth years satisfied the criteria, and they were all included in the study. Three ICT and four LIS lecturers who were teaching a course during the semester the study was being conducted were 
interviewed on some issues raised by the students through the questionnaire. The study was conducted in three phases. Firstly, a Web-based questionnaire consisting of only closedended questions was sent to 186 students. The questionnaire was administered at the end of the first semester of the 2014-2015 academic year. Secondly, the curricula of the faculty were analysed by looking for Web 2.0 elements in 43 LIS and 44 ICT courses. Finally, follow-up interviews were conducted with the seven lecturers mentioned above. Using an interview protocol, the lecturers were asked various questions with the aim of seeking clarification on some claims made by the students and some inconsistencies noted in the curricula. For example, the lecturers were asked to comment on the finding that of the 136 students who answered the questionnaire, only 48 (35.3\%) indicated that they were encouraged by their lecturers to use Web 2.0 in their academic activities. Or given that only $7(16.2 \%)$ of the 43 LIS and $8(18.8 \%)$ of the 44 ICT courses that were analysed mentioned Web 2.0 explicitly, what measures they were taking to integrate them. This technique enabled the researchers to obtain additional in-depth data that helped shed more light on the student's use of Web 2.0 technologies by triangulating data from the three sources.

\section{Results and discussion Background information}

Of the 186 students to whom the questionnaire was sent, $136(73.1 \%)$ responded. Seventy-nine (58\%) men and 57 (42\%) women responded to the questionnaire. In Malawi, the enrolment ratio of women to men in universities is considerably lower, and this explains the disparity between the number of women and men who responded to the questionnaire. According to the World Bank (2010), female enrolment in Malawian public universities has remained at around $30 \%$. Eighty-three $(61 \%)$ respondents are LIS students, whereas $53(39 \%)$ are students from the ICT department. The findings suggest that the LIS department enrols more students than the ICT department. Because the model adopted (see Taylor \& Todd 1995) informed the questionnaire questions, issues to do with age and experience, which are of great importance in behavioural intention to use technologies (Venkatesh et al. 2003), were not investigated. Of the 136 respondents, 54 (39.71\%) were in level two, 47 (34.56\%) in level three and 35 (25.74\%) in level four. According to the findings, it is clear that there are more students in lower classes than in higher levels of study. One of the reasons for the decline in the number of students as they progress to higher levels of studies at MZUNI is the high failure rates (commonly called withdrawal of students on academic grounds) (Zozie \& Kayira 2012). Zozie and Kayira (2012:435) report that between the 2009-2010 and 2010-2011 academic years, 103 students were withdrawn from the university on academic grounds.

\section{Awareness of and familiarity with Web 2.0 technologies}

Students were asked to indicate the Web 2.0 technologies they knew. The study established that, in this order, 135
(99.3\%), 134 (98.5\%), 127 (93.3\%), 115 (84.5\%), 112 (82.3\%), $109(80.7 \%)$ and $100(73.6 \%)$ students were aware of Facebook, YouTube, Wikipedia, WhatsApp, Skype, Google Apps and Twitter. However, only 48 (35.3\%) students or fewer were aware of blogs, podcasts, Dropbox, RSS feeds, Viber, LinkedIn, Picasa, Flickr and Delicious. The results suggest that social networking sites are amongst the most popular Web 2.0 technologies at MZUNI.

Figure 3 provides the findings in terms of proficiency with Web 2.0, where it is clear that the students were more competent in using some Web 2.0 technologies than others. Precisely 129 (94.8\%), 100 (73.6\%), 97 (71.4\%), 95 $(69.8 \%), 90(66.1 \%), 89(65.5 \%)$ and $80(60.8 \%)$ students indicated that they are able to use Facebook, WhatsApp, Wikipedia, Google Apps, YouTube, Twitter and Skype, respectively. Some of these Web 2.0 technologies, such as Twitter, blogs, YouTube and wikis, are explicitly covered in the curricula, and this is the reason why the students were able to use them proficiently. For example, an extract from End-user Computing (ICT1101), which is a compulsory course for both LIS and ICT students reads, '[S]tudents should be able to use media sharing sites such as Twitter, blogs, YouTube, wikis, etc.', implying that students learn some of these technologies in class. The questionnaire and curricula findings are further supported by the responses from the lecturers interviewed. For instance, one lecturer commented:

I have taught both LIS and ICT students, and I have not just encouraged them but rather forced them to use these technologies. For example, I usually tell them I will not mark the assignment if they do not upload and share it with me on Google Drive.

A cross-tabulation of the findings reveals that the students in levels three and four were more proficient in using YouTube, wikis and blogs than those in level two. An analysis of the curriculum reveals that it covers more Web 2.0 technologies at these levels than at levels one and two.

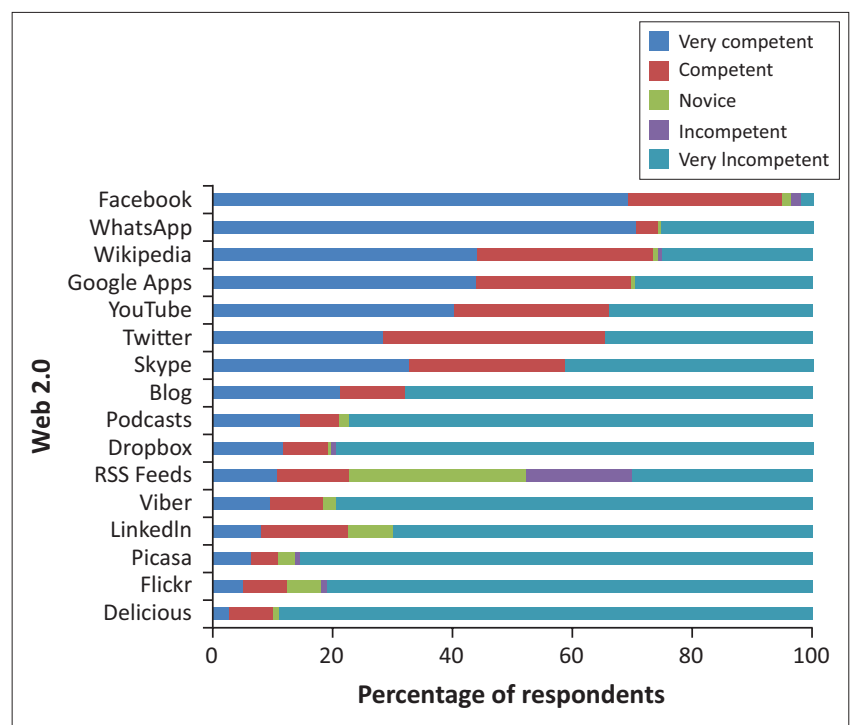

FIGURE 3: Competency in the use of Web 2.0 by students. 
The results presented in Figure 3 show that students cannot use some technologies that they are not aware of. For example, the students possessed limited or zero knowledge, abilities and skills for using Delicious, Flickr, Picasa, Viber, Dropbox and podcasts mainly because most of these technologies are conspicuously missing in the curricula. Although other technologies such as RSS feeds, blogs and Sound Cloud are supposed to be embedded in their learning, as indicated by the learning outcomes of Web Design (ICT2402), only a few students were able to use them. Lecturers may have skipped teaching some of these technologies because of time constraints. Some lecturers mentioned during the interviews that students tend to use Web 2.0 technologies that they are interested in, such as Google Drive, Twitter and WhatsApp, especially if the technologies can be used for personal reasons as well. Students do not see the value (perceived usefulness according to the DTPB) of some of the technologies that they learn in class, such as blogs and RSS feeds. Students' lack of knowledge and skills in using some Web 2.0 technologies is not unique to Malawi. In South Africa, Mugwanya, Marsden and Boateng (2011) investigated lecturers' and students' experience in podcasting at the University of Cape Town to determine their current experiences, familiarity and knowledge. The researchers report that lecturers and students lack the necessary knowledge and experience in podcasting, and consequently, they have a perception that podcasts do not provide much needed value in the teaching and learning process.

Although there are several points of Internet access on the MZUNI campus and in the surrounding communities, the study shows that the majority of the students (83.5\%) used the Internet room in the university library. In addition to the Internet room in the university library, 95 (74.8\%) students used the American Corner Internet Café (situated on the MZUNI campus), 69 (54.3\%) students used the privately owned Internet Café outside the university campus and $42(33.1 \%)$ students used the faculty computer laboratory. The fact that the highest number of students accessed these technologies in the library supports the claims by Chaputula (2012:377) that most students at MZUNI access the Internet in the university Internet room. In the present study, it is not surprising that the students used the library, which has computers, because, according to the DTPB model informing this study, individuals are expected to use the technology if computers and Internet facilities (technology-facilitating conditions) are made available.

\section{Purpose and most popular choices of Web 2.0}

The students were asked to indicate the personal and academic activities that they performed using Web 2.0 technologies. The findings reveal that all $136(100 \%)$ students used Web 2.0 technologies for schoolwork, 124 (92.5\%) for social activities and 75 (51.1\%) for other purposes. Only 23 (17.2\%) respondents used these technologies to hunt for jobs.
According to the findings, the social activities included connecting with new friends, chatting with friends and entertainment. The results suggest that students in the Faculty of ISC use Web 2.0 technologies (Twitter, WhatsApp, Facebook, and YouTube) to interact with their friends at the university or at home and to watch movies and documentaries.

Students in the Faculty of ISC use Web 2.0 technologies to accomplish five main academic activities worth reporting. As can be seen in Figure 4, 69 (50.7\%) or more students used these Web 2.0 technologies to search for information, to communicate with lecturers, to submit assignments, to communicate with friends on academic work and to share content with fellow students. The emerging evidence that students use Web 2.0 technologies to communicate with one another lends support to the findings by Li and Pitts (2009) and Eyyama, Menevi and Dogruer (2011), who observed that Web-based technologies have significantly transformed the ways in which students and lecturers communicate with one another. The results from this study strongly reveal that lecturers use Web 2.0 technologies to distribute lecture notes and assignments and provide feedback to learners, and students use these technologies to share their completed assignments with lecturers. The findings give substance to those reported by Dzvapatsva, Mitrovic and Dietrich (2014), who found that most Further Education and Training students doing Computer Programming in South Africa indicated that social networks, especially Facebook, make communication convenient between lecturers and students.

The results of the questionnaire, as shown on the graph (Figure 5), reveal that between 66 (45.8\%) and 95 (69.9\%) students used Wikipedia, WhatsApp, Google Apps and YouTube to accomplish various academic activities. Interviews with the lecturers reveal that BlackBerry Messenger (BBM) is also used. For example, one of the lecturers commented:

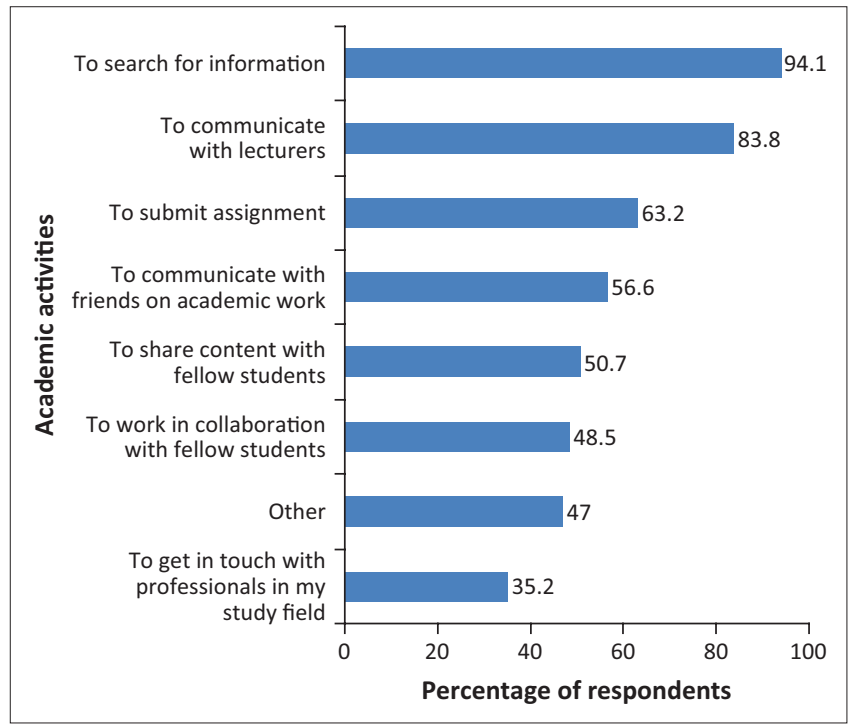

FIGURE 4: Educational activities accomplished using Web 2.0 technologies $(N=136)$. 


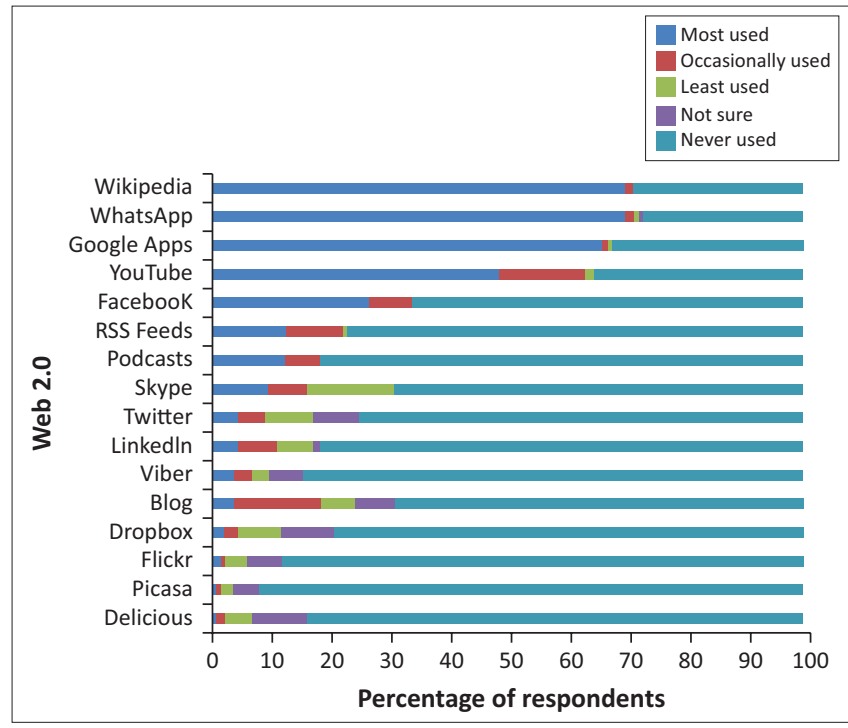

FIGURE 5: Web 2.0 technologies used to accomplish academic activities.

'Although I have been using BBM for a long time [to communicate with students and colleagues], I now encourage students to use Twitter to share information or articles related to my course'.

In a bid to facilitate independent learning, students were encouraged by lecturers to use YouTube videos to broaden their knowledge horizons. YouTube, which is understood to have been adopted as the de facto video sharing for social networking and education content, is preferred to other technologies like podcasts because of its integration of images, text and audio, presenting a comprehensive wealth of learning opportunities. Thus, it is possible to notice how the aspect of perceived usefulness, conceived by Taylor and Todd (1995), applies to this finding. In this case, the students used YouTube in particular because it adds value by helping them learn some concepts without the intervention of their lecturers.

Although the current study found that Web 2.0 technologies are used to facilitate collaborative learning, as similarly reported by various researchers (Ajjan \& Hartshorne 2008; Tur \& Marín 2015:51), the main avenue for conducting collaborative learning is limited to Google Apps. Evidence emerged that students are yet to harness other opportunities that come along with these Web 2.0 technologies. Some of these opportunities include the collaborative review of course content using wikis and blogs (Al-Qirim 2010; De Wever et al. 2015) and accessing course materials collaboratively, posting reflections on work covered in class and viewing the work posted by other students (Churchill 2009). The prime reason for the non-use of wikis and blogs for these purposes is that the majority of students felt that they are not able to use blogs, although they appear to have been taught how to use them in class, as revealed in the curricula. Furthermore, despite being clear that they had the skills for searching information on wikis or Wikipedia, the study did not establish if the students had hands-on experience creating a wiki. Rather, the study established that the students had the skills and knowledge required for searching information in already constructed wikis and blogs. In practice, it appears that students do not use these technologies as co-creators or publishers of information. Instead, they use them as mere consumers of content.

\section{Factors for the use or non-use of Web 2.0 by students}

Some researchers (e.g. Gaffar, Singh \& Thomas 2011) observe that although it is becoming increasingly common knowledge that Web 2.0 technologies come along with various benefits and opportunities in university environments, the factors that affect their adoption may vary from country to country and from university to university. Thus, data were solicited from the students about the factors that swayed them to use or not to use Web 2.0. It was revealed that the students used these technologies for three major reasons: 131 (96.3\%) were in agreement that they used Web 2.0 technologies because they had the knowledge and the ability, 122 (89.7\%) because Web 2.0 technologies fit with their learning practices, and 77 (56.6\%) because they could access these technologies for free. These responses resonate well with the DTPB. In line with the DTPB perspectives, the students adopted some Web 2.0 technologies because they were able to easily understand and operate them (ease of use) and these technologies fit well with their learning practices and experiences (compatibility).

There are two main reasons for non-use of these technologies. Seventy-four (54.4\%) students agreed that they did not use Web 2.0 because the bandwidth was poor, and 51 (37.5\%) students agreed that they did not use these technologies because they put their privacy at risk. Surprisingly, only 43 (31.6\%) students indicated that frequent electricity outages discouraged them from using Web 2.0 technologies, contradicting the findings by Nyirongo (2009) that power outages at MZUNI discouraged lecturers from adopting the Internet in their academic activities. However, the interviews with the lecturers reveal that the problem of power outages does exist at MZUNI. For example, four lecturers were of the view that shortage of electricity is a huge impediment to Web 2.0 access, thereby disagreeing with the students' claims. A statement by one of the lecturers provides an important hint about what may have swayed students not to regard electricity outages as a problem. The lecturer says, 'The advantage is that students still access Web 2.0 technologies via smartphones when there is no electricity'. In other words, students could still access Web 2.0 technologies all day without being affected by electricity hitches experienced on campus.

The study found that infrastructure difficulties at MZUNI adversely affect students' use of the faculty computer laboratory as an access point for Web 2.0 technologies because, slowly but surely, the faculty computer laboratory has started serving other departments and faculties as a teaching venue. The situation is worsened by a negligible amount of Wi-Fi at MZUNI. According to Nyirongo (2009) and Stav et al. (2010), Wi-Fi is one of the factors that motivate 
students to use technologies (Web 2.0) in their academic activities. The unavailability of Wi-Fi results in the congestion of the already small library Internet room, where, according to Nyirongo (2009:72), the library staff sometimes ration students' access because computers are insufficient. It appears that previously there was Wi-Fi at MZUNI, because Nyirongo (2009:62) reports that Wi-Fi Internet technology is installed at the university, although the study does not explicitly mention whether the Wi-Fi covered the whole university campus. Based on these findings, it appears that the digital divide is a reality at MZUNI. Similarly, Gaffar, Singh and Thomas (2011) noted that students fail to use some Web 2.0 technologies because of poor bandwidth, lack of ICT skills and an inadequate number of computers.

\section{Conclusion and recommendations}

By adopting mixed methods, the study has shown MZUNI students' use and awareness of and familiarity with Web 2.0 technologies. Although all students (levels two to four) in the Faculty of ISC were aware of the existence of most Web 2.0 technologies, some students, particularly those in levels three and four, had more knowledge of Web 2.0 technologies that could be used to accomplish academic activities. A good number of students in the faculty predominantly used Wikipedia, Google Apps, YouTube, WhatsApp, BBM and Twitter to accomplish their academic activities. The dominant activities that the students performed using these technologies included searching for information or content, communicating (submitting assignments to and receiving feedback from lecturers) and conducting collaborative learning. Two attributes of the DTPD, namely attitude (perceived usefulness, ease of use and compatibility) and perceived behaviour control (self-efficacy and resource- and technologyfacilitating conditions), were the key determining factors that positively influenced the students to adopt Web 2.0 technologies in their academic activities. Although the students have enthusiastically made some progress in adopting some Web 2.0 technologies in their academic activities, two major limiting factors were noted: the absence of Wi-Fi at MZUNI and the continued use of the faculty computer laboratory by other departments as a learning venue. The study recommends that the MZUNI management through the Department of ICT Directorate should install robust and reliable Internet (Wi-Fi) across the campus so that students can seamlessly access these technologies everywhere on campus.

\section{Acknowledgements Competing interests}

The authors declare that they have no financial or personal relationships that may have inappropriately influenced them in writing this article.

\section{Authors' contributions}

W.C. and S.Z. contributed equally to the writing of this article.

\section{References}

Abram, S., 2007, 'Web 2.0, library 2.0, and librarian 2.0: Preparing for the 2.0 world', in S. Ricketts, C. Birdie \& E. Issackson (eds.), Library and information services in astronomy, vol. 377, pp. 161-167, viewed 10 June 2014, from http://adsabs. harvard.edu/full/2007ASPC..377..161A

Ajjan, H. \& Hartshorne, R., 2008, 'Investigating faculty decisions to adopt Web 2.0 technologies: Theory and empirical tests', Internet and Higher Education 11(2), 71-80. http://dx.doi.org/10.1016/j.iheduc.2008.05.002

Ajzen, I., 1991, 'The theory of planned behaviour', Organizational Behaviour and Human Decision Processes 50(3), 179-211. http://dx.doi.org/10.1016/07495978(91)90020-T

Alexander, B., 2006, 'Web 2.0: A new wave of innovation for teaching and learning?' Educause Review 41(2), 32-44.

Al-Qirim, N., 2010, 'Critical success factors for pedagogy 2.0', in Proceedings of International Symposium on Science 2 and Expansion of Science: S2ES, Orlando, July 19-22, 2010, viewed 20 July 2014, from http://www.iiis.org/CDs2011/ July 19-22, 2010, viewed 20 July 2014, from

Armstrong, J. \& Franklin, T., 2008, A review of current and developing international practice in the Web 2.0 in higher education, viewed 10 June 2014, from http:// practice in the Web 2.0 in higher education, viewed 10 June 2014 , from http:// social\%20networking\%20in\%20HE.pdf

Augustsson, G., 2010, 'Web 2.0 pedagogical support for reflexive and emotional social interaction among Swedish students', Internet and Higher Education 13, 197-205. http://dx.doi.org/10.1016/j.iheduc.2010.05.005

Azab, A.N., Abdelsalam, M.H. \& Gamal, S., 2013, 'Use of Web 2.0 collaboration technologies in Egyptian public universities: An exploratory study', in Z. Mahmood (ed.), E-government implementation and practice in developing countries, pp. 99-127, IGI Global, Hershey.

Beebe, M.A., 2004, 'Impact of ICT revolution on the African academic landscape', in CODESRIA Conference on Electronic Publishing and Dissemination, Senegal, Dakar, September 1-2, 2004, pp. 1-14.

Bull, G., Thompson, A., Searson, M., Garofalo, J., Park, J., Young, C. \& Lee, J., 2008, 'Connecting informal and formal learning experiences in the age of participatory media', Contemporary Issues in Technology and Teacher Education 8(2), 100-107.

Campion, R.S. \& Nailda, F.N., 2012, 'Web 2.0 and higher education: Its education use in the university environment', European Journal of Open, Distance and E-Learning 2, viewed 05 March 2014, from http://www.eurodl.org/?p=archives\&year=2012\& halfyear $=2$ \&article $=535$

Chaputula, A.H., 2012, 'State, adoption and use of ICTs by students and academic staff at Mzuzu University, Malawi', Program: Electronic Library and Information Systems 46(4), 364-382. http://dx.doi.org/10.1108/00330331211276477

Chaputula, A.H. \& Boadi, B.Y., 2010, 'Funding for collection development activities at Chancellor College Library, University of Malawi', Collection Building 29(4), 142-147. http://dx.doi.org/10.1108/01604951011088871

Chisa, K.D., 2006, 'A comparative study of the role of donors in three telecentre projects in Africa', PhD thesis, Department of Information Studies, University of KwaZulu-Natal, Pietermaritzburg.

Chiu, C.M. \& Wang, E.T., 2008, 'Understanding Web-based learning continuance intention: The role of subjective task value', Information \& Management 45(3), 194-201. http://dx.doi.org/10.1016/j.im.2008.02.003

Churchill, D., 2009, 'Educational applications of Web 2.0: Using blogs to support teaching and learning', British Journal of Educational Technology 40(1), 179-183. http://dx.doi.org/10.1111/j.1467-8535.2008.00865.x

Davis, F., 1989, 'Perceived usefulness, perceived ease of use, and user acceptance of information technology', MIS Quarterly 13(2), 319-339. http://dx.doi.org/ $10.2307 / 249008$

De Wever, B., Hämäläinen, R., Voet, M. \& Gielen, M., 2015, 'A wiki task for first-year university students: The effect of scripting students' collaboration', The Internet and Higher Education 25, 37-44. http://dx.doi.org/10.1016/j.iheduc.2014.12.002

Dzvapatsva, G.P., Mitrovic, Z. \& Dietrich, A.D., 2014, 'Use of social media platforms for improving academic performance at Further Education and Training Colleges', South African Journal of Information Management 16(1). http://dx.doi.org/ 10.4102/sajim.v16i1.604

Eyyama, R., Menevi, I. \& Dogruer, N., 2011, 'Perceptions of teacher candidates towards Web 2.0 technologies', Procedia Social and Behavioural Sciences 15(5), 2663-2666. http://dx.doi.org/10.1016/j.sbspro.2011.04.166

Franklin, T. \& Harmelen, M., 2007, Web 2.0 for content for learning and teaching in higher education, JISC, Bristol, viewed 20 February 2016, from http://www. webarchive.org.uk/wayback/archive/20140614142108/http://www.jisc.ac.uk/ media/documents/programmes/digitalrepositories/web2-content-learning-andteaching.pdf

Gaffar, K., Singh, L. \& Thomas, T., 2011, 'Are we ready for Web 2.0? Evidence from a Caribbean University', Caribbean Teaching Scholar 1(2), 129-146.

Gakio, K., 2006, African tertiary institutions connectivity survey, viewed 10 February 2015, from http://ahero.uwc.ac.za/index.php?module=cshe\&action=viewtitle\& id $=$ cshe_172

Grosseck, G., 2009, 'To use or not to use Web 2.0 in higher education?', Procedia Social and Behavioural Sciences 1(2), 478-482. http://dx.doi.org/10.1016/j. sbspro.2009.01.087

Habib, M.C., 2006, 'Towards academic library 2.0: Development and application of a library 2.0 methodology', Master's thesis, School of Information and Library Science, University of North Carolina. 
Harinarayana, N. \& Raju, V., 2010, 'Web 2.0 features in university library web sites', The Electronic Library 28(3), 69-88. http://dx.doi.org/10.1108/02640471011023388

Hartley, J., 2004, Essential guide to qualitative methods in organizational research, Sage, London. http://dx.doi.org/10.4135/9781446280119

Hartshorne, R. \& Ajjan, H., 2009, 'Examining student decisions to adopt Web 2.0 technologies: Theory and empirical tests', Journal of Computing in Higher Education 21(3), 183-198. http://dx.doi.org/10.1007/s12528-009-9023-6

Hough, J. \& Neuland, E., 2012, 'Comparison of Web 2.0 on-line usage by on campus and distance learning students', viewed 04 September 2015, from http://www. icicte.org/Proceedings2012/Papers/01-1-Hough.pdf

Huang, W.H.D., Hood, D.W. \& Yoo, S.J., 2013, 'Gender divide and acceptance of collaborative Web 2.0 applications for learning in higher education', The Internet and Higher Education 16, 57-65. http://dx.doi.org/10.1016/j.iheduc. 2012.02.001

Ibrahim, R., Khalil, K. \& Jaafar, A., 2011, 'Towards educational games acceptance model (EGAM): A revised unified theory of acceptance and use of technology (UTAUT)', International Journal of Research and Review in Computer Science 2(3), (UTAUT)',
839-846.

International Telecommunication Union, 2014, Transforming Africa: The promise of broadband, viewed 11 November 2014, from https://www.itu.int/en/ITU-D/ broadband, viewed 11 November 2014, from https://www.itu.int/en/ITU-D/ Conferences/connect/Documents/
Report $\% 20 \% 28$ English\%29.pdf

Jones, A., 2015, 'How Twitter saved my literature class: A case study with discussion', in C. Wankel, M. Marovich, K. Miller \& J. Stanaityte (eds.), Teaching arts and science with the new social media, pp. 91-105, Emerald Group Publishing, Bingley. science with the new social media, pp. 91-105, Emerald Group
$\mathrm{http} / / / \mathrm{dx}$.doi.org/10.1108/S2044-9968(2011)0000003008

Kaplan, A. \& Haenlein, M., 2010, 'Users of the world, unite! The challenges and opportunities of social media', Business Horizons 53(1), 59-68. http://dx.doi.org/ 10.1016/j.bushor.2009.09.003

Komiko, L., 2007, Web 2.0 in libraries, Open University, University of Michigan.

Kumar, S., 2009, 'Undergraduate perceptions of the usefulness of Web 2.0 in higher education: Survey development', in D. Remenyi (ed.), Proceedings of the European Conference on e-Learning, Bari, Italy, October 29-30, 2009, pp. 308-314.

Kwanya, T., Stilwell, C. \& Underwood, P., 2012, 'The application of Web 2.0 tools by libraries in Kenya: A reality check', in SCECSAL XXth Conference, Nairobi, June 4-8, 2012, viewed 10 April 2015, from http://scecsal.viel.co.ke/images/e/ ea/The_Application_Of_Web_2.0_Tools_By_Libraries_In_Kenya-_A_Reality Check.pdf

Li, L. \& Pitts, J., 2009, 'Does it really matter? Using virtual office hours to enhance student-faculty interaction', Journal of Information Systems Education (20) 175-185.

Luo, L., 2010, 'Web 2.0 integration in information literacy instruction: An overview', Journal of Academic Librarianship 36(10), 32-40. http://dx.doi.org/10.1016/j. acalib.2009.11.004

Lwoga, E., 2012, 'Making learning and Web 2.0 technologies work for higher learning institutions in Africa', Campus-Wide Information Systems 29(2), 90-107. http://dx.doi.org/10.1108/10650741211212359

Makori, E.O., 2011, 'Bridging the information gap with the patrons in university libraries in Africa: The case for investments in Web 2.0 systems', Library Review 61(4), 30-40. http://dx.doi.org/10.1108/00242531211207406

Mascolo, M.F., 2009, 'Beyond student-centered and teacher-centered pedagogy: Teaching and learning as guided participation', Pedagogy and the Human Sciences $1(1), 3-27$.

McMillan, J.H., 2004, Educational research: Fundamentals for the consumer, 4th edn., Pearson, New York.

Menkhoff, T., Chay, Y.W., Bengtsson, M.L., Woodard, C.J. \& Gan, B., 2014, 'Incorporating microblogging ("tweeting") in higher education: Lessons learnt in a knowledge management course', Computers in Human Behavior. http://dx.doi.org/10.1016/j chb.2014.11.063

Mtingwi, J. \& Van Belle, J., 2012, 'The state of e-government and m-government readiness in Malawi', International Journal of Information Technology \& Computer readiness in Malawi',
Science $6(1), 58-68$. Mugwanya, R., Marsden, M. \& Boateng, R., 2011, 'A preliminary study of podcasting
in developing higher education institutions', Journal of Systems and Information Technology 13(3), 268-285. http://dx.doi.org/10.1108/13287261111164853
Musser, J. \& O'Reilly, T., 2007, Web 2.0 principles and best practices, O'Reilly Media, Sebastopol.

Mzuzu University, 2015, Mzuzu University prospectus, Mzuzu University, Mzuzu.

Nyirongo, K.N., 2009, 'Technology adoption and integration: A descriptive study of a higher education institution in a developing nation', PhD thesis, Department of Education, Virginia Polytechnic Institute and State University, Blacksburg.

O'Neill, G. \& McMahon, T., 2005, 'Student-centred learning: What does it mean for students and lecturers?', in G. O'Neill, S. Moore \& B. McMullen (eds.), Emerging issues in the practice of university learning and teaching, All Ireland Society for Higher Education, Dublin, viewed August 2015, from http://www.aishe.org/ readings/2005-1/oneill-mcmahon-Tues_19th_Oct_SCL.pdf

O'Reilly, T., 2005, What is Web 2.0: Design patterns and business models for the next generation of software?, O'Reilly Media, Sebastopol, viewed 10 July 2014, from https://mpra.ub.uni-muenchen.de/4578/1/MPRA_paper_4578.pdf

Palfrey, J. \& Gasser, U., 2008, Born digital: Understanding the first generation of digital natives, Basic Books, New York.

Rogers, E.M., 2003, Diffusion of innovations, 5th edn., Free Press, New York.

Sadaf, A., Newby, T.J. \& Ertmer, P.A., 2012, 'Exploring factors that predict preservice teachers' intentions to use Web 2.0 technologies using decomposed theory of planned behavior', Journal of Research on Technology in Education 45(2), 171-196. hlanned behavior', Journal of Research on Technology in

Sandars, J. \& Schroter, S., 2007, 'Web 2.0 technologies for undergraduate and postgraduate medical education: An online survey', Postgraduate Medical Journal 83(986), 759-762. http://dx.doi.org/10.1136/pgmj.2007.063123

Schroeder, J. \& Greenbowe, T.J., 2009, 'The chemistry of Facebook: Using social networking to create an online community for the organic chemistry laboratory', Innovate: Journal of Online Education 5(4), 1-7.

Shihab, M., 2008, 'Web 2.0 tools improve teaching and collaboration in English language classes', paper presented at the National Educational Computing Conference, Henry B. Gonzalez Convention Centre, San Antonio, 29th June-2nd July.

Soares, D.A., 2008, 'Understanding class blogs as a tool for language development', Language Teaching Research 12(4), 517-533.

Stav, J., Nielsen, K., Hansen-Nygard, G. \& Thorseth, T., 2010, 'Experiences obtained with integration of student response systems for iPod touch and iPhone into e-learning environments', Electronic Journal of e-Learning 8(2), 179-190.

Tatnall, A., Paull, S., Burgess, S. \& Davey, B., 2003, Business information systems, Data Publishing, Heidelberg.

Taylor, S. \& Todd, P.A., 1995, 'Understanding information technology usage: A test of competing models', Information Systems Research 6(2), 144-176. http://dx.doi. org/10.1287/isre.6.2.144

Tur, G. \& Marín, V.I., 2015, 'Enhancing learning with the social media: Student teachers' perceptions on Twitter in a debate activity', New Approaches in Educational Research 4(1), 46-53. http://dx.doi.org/10.7821/naer.2015.1.102

Tyagi, S., 2012, 'Adoption of Web 2.0 technology in higher education: A case study of universities in National Capital Region, India', International Journal of Education and Development Using Information and Communication Technology 8(2), 28-43.

Venkatesh, V., Morris, M.G., Davis, G.B. \& Davis, F.D., 2003, 'User acceptance of information technology: Toward a unified view', MIS Quarterly 27, 425-478.

Wheeler, S., 2010, 'Open content, open learning 2.0: Using wikis and blogs in higher education', in E. Ulf-Daniel \& S. Dirk (eds.), Changing cultures in higher education: Moving ahead to future learning, pp. 103-114, Springer, Berlin. http://dx.doi. org/10.1007/978-3-642-03582-1

World Bank, 2010, The education system in Malawi, working paper, International Bank for Reconstruction and Development, Washington, DC.

Zimmer, M., 2008, 'Critical perspective on Web 2.0', First Monday 13, 3-3, viewed 10 August 2015, from http://www.uic.edu/htbin/cgiwrap/bin/ojs/index.php/fm/ article/view/2137/1943

Zinn, S., 2009, 'Readiness to adopt e-learning: Pioneering a course in school librarianship education', South African Journal of Libraries and Information librarianship education', South African Journal of Libraries
Science 75(2), 159-169. http://dx.doi.org/10.7553/75-2-96

Zozie, P.A. \& Kayira, P.B., 2012, 'Transition and tertiary education: A case study of Mzuzu University, Malawi', Research in Comparative and International Education 7(4), 434-445. http://dx.doi.org/10.2304/rcie.2012.7.4.434 